Péter Pavletits

\title{
The Role and Possibilities of Hungarian Narrow-Gauge \\ Railways in Tourism
}

\begin{abstract}
Since the 1980's almost all of the the Hungarian narrow-gauge railway lines made a complete change of function. In the following decade with a few exceptions the freight was completely abolished and replaced by tourism. We need to address several factors if we want to determine the tourism potential of a particular narrow-gauge railway. One of these is accessibility, which shows what extra effort a tourist needs to make to get to a particular attraction. It is not enough just to look at accessibility, we also need to look how narrow-gauge railways can get involved in the tourism system. In a tourism approach we can examine points of interest from several perspectives. The interdependent material conditions of tourism include basic infrastructure, attraction and tourism infrastructure. The basic infrastructure in tourism means the existence of conditions that are essential to see the attraction. Several narrowgauge railways also play a role in the basic infrastructure, however, their most significant role is the dynamic infrastructure. The narrow-gauge railway transports tourists to the tourist attraction, or due to its nature, attracts tourists. Most of the Hungarian narrow-gauge railway fall into the category of dynamic infrastructure. Attraction is difficult to define, because there are a lot of subjective elements, but most of the Hungarian narrow-gauge railways we can definitely highlight and call as real attractions. It is important to talk about seasonality. Not all of them offer the same experience in summer as in winter, they are not the same attractions in all seasons. By tourist milieu we mean the attraction of the destination, the totality of the experiences gained there.
\end{abstract}

Keywords: narrow-gauge railway, tourism, infrastructure, attraction, milieu

\section{Their touristical significance}

The Hungarian narrow-gauge railway system has undergone almost a complete change of function since the 1980's. In the following decade, the previous transport of goods, with a few exceptions, ceased altogether and was replaced by tourism. Most of our narrow-gauge railway lines were built for freight transport and passenger demand started to grow on them, some lines were created specifically for the transport of tourists. They can be involved in the tourism system in several areas; however, tourism cannot maintain the railway lines. In some railways, the number of visitors is more than 200,000 per year (Szilvásvárad, Lillafüred), ticket revenues do not cover the costs of operation, so the operator has to supplement it from its own resources. The deficit of narrow-gauge railways is offset by profits from other areas.

The railway can only extract the cost of its own operation in areas where there is also freight. Two lines in Hungary are the Lenti-Csömödér narrow-gauge railway system, and the Gemenc State Forest Railway where a significant part of the supply of timber harvested by forestry is the main profile, which can also compensate for the deficit of passenger transport. 
Map 1: The public narrow-gauge railway lines in Hungary in 2017.

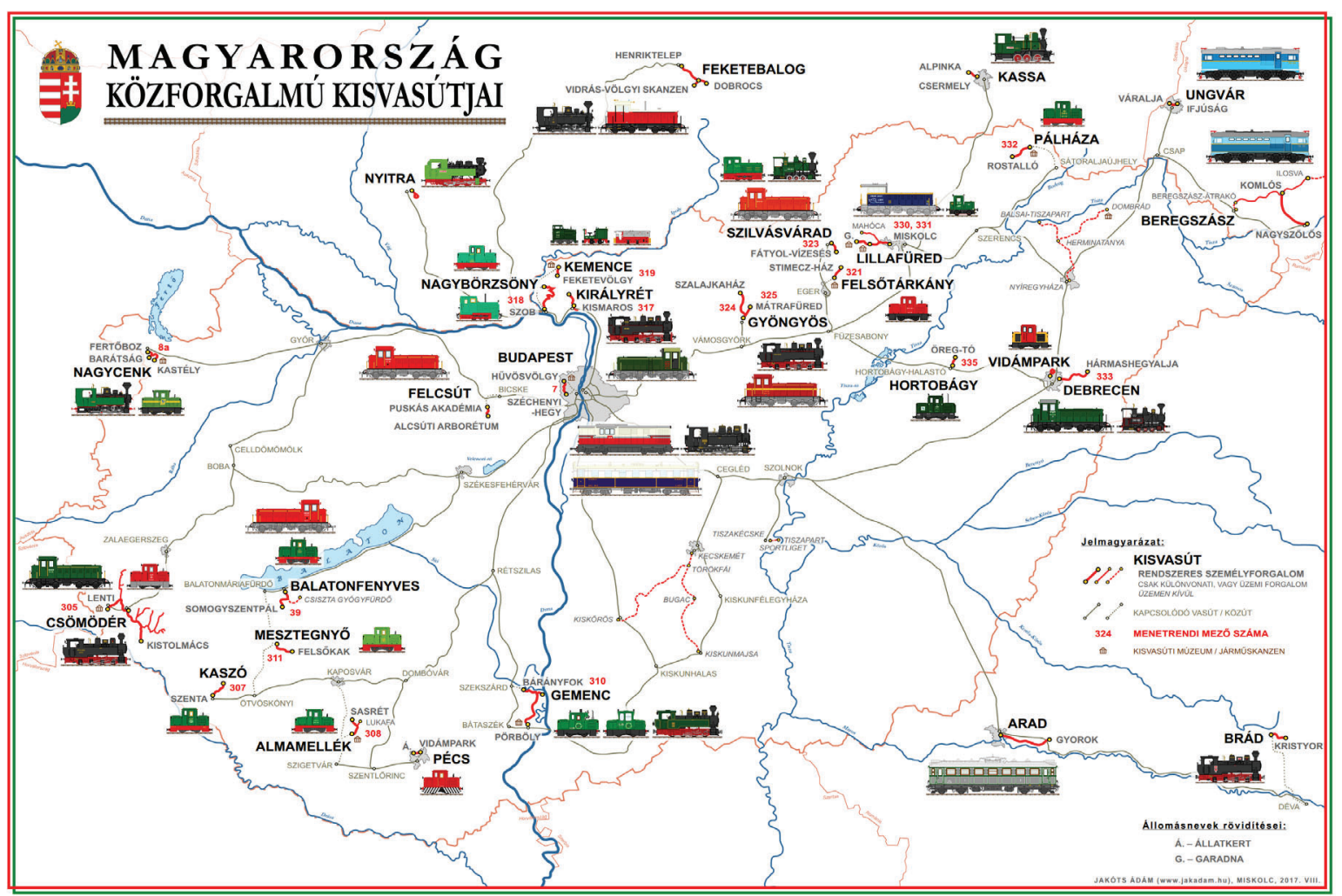

Source: Edited by Ádám Jakóts, 2017

We need to address several factors if we want to determine the tourism potential of a given area. One of these is accessibility, which shows what extra effort a tourist needs to make to get to that particular attraction. If we consider narrow-gauge railways as attractions in their own right, we need to look at how they can be reached most conveniently and quickly from a given point. It greatly improves the attendance of attractions if they are accessible with direct or minimal transfer. ${ }^{1}$ One such concrete example is the case of Lillafüred belonging to Miskolc, which was accessible in the 1930's with a single direct transfer from Budapest. It has been able to host several prestigious events, including its location and good accessibility. Nowadays, we have to change public transport at least twice and travel conditions have deteriorated significantly since the beginning of the $20^{\text {th }}$ century.

Unfortunately, today the Hungarian narrow-gauge railways are operating as remnants of former lines which have been partially liquidated. In several cases, the liquidated sections have connected the lines running mostly in the depths of forests with the national railway network (Felsőtárkány, Pálháza). Thus, the number of narrow-gauge railways directly connected to the national network has dropped significantly. The number of those located along highways is even lower. In many cases, this fact also hinders the popularity of the attraction, because in some cases the Hungarian narrow-gauge lines are located in hidden valleys, in places only accessible by third and fourth-order roads. In this respect, a solution could be to extend the narrow-gauge railways to the main highways or to the national rail network, thus ensuring better access. An excellent example of this is the Gödöllö Forest Railway, which is being built in the catchment area of the capital and it is also planned to have a major rail link in the medium term.

Unfortunately, some lines are located at a considerable distance not only from Budapest, but even from the headquarters of the given county. One of the worst situations has the Kaszó Forest Railway, which can only be reached from Kaposvár with a minimum of two transfers. Of course,

1 Michalkó, Gábor: Magyarország modern turizmusföldrajza. Budapest-Pécs, 2007. 140. 
based on the distances alone, it is not possible to draw exact conclusions, but we observe that among the lines far from the capital city, the traffic is really significant (Szilvásvárad, Lillafüred) where there is another attraction besides the railway, we can say, the narrow-gauge railway takes you somewhere. There are always exceptions, of course, there is a significant tourism potential at the Pálháza Forest Railway, which is located near the largest tourism development of the 2000's (Zemplén Adventure Park). An all-day program can be a forest train ride after visiting the adventure park.

\section{Narrow-gauge railways as tourist attractions}

It is not enough to just look at accessibility, we also need to look at how narrow-gauge railways can get involved in the tourism system. In a tourism approach, we can examine points of interest from several perspectives. The interdependent material conditions of tourism include basic infrastructure, attraction and tourism infrastructure. ${ }^{2}$ These factors are well identifiable on narrow-gauge railways, but we need to mention something else as an attraction. All Hungarian narrow-gauge railways can be classified into one of the infrastructural categories of tourism, some lines into more than one, so they are involved in tourism on several levels. I present this categorization from the basic infrastructure to the attraction and to the dynamic infrastructure.

\section{Narrow-gauge railways as part of the basic infrastructure}

The basic infrastructure in tourism means the existence of the conditions necessary for seeing the attraction. The most important elements are the existence of transport, communication and utilities. ${ }^{3}$ In this sense, we need to look at narrow-gauge railways as static and dynamic elements of basic transport infrastructure.

\section{Static basic infrastructure}

The primary goal of infrastructure developments is to improve the quality of life of local residents, but the development of rural tourism is also a basic and important requirement. The development of rural tourism in Hungary began in the early 1930's, and after a forced break during socialism it began to develop spontaneously again in the early 1990 's. ${ }^{4}$

Several Hungarian narrow-gauge railways also play a role in the basic infrastructure. In many cases, the area they explore cannot be approached otherwise, at most on foot. However, in many cases, hikers can only walk on the railway line. The best example of this is the Gemenc State Forest Railway, operating in the Gemenc Landscape Protection Area, which is used not only by tourists, but also in the care of animals living in the nature reserve, in addition to forestry logging. The only public transport in the Gemenc park forest is the narrow-gauge railway, which also offers tourists an opportunity to visit the otherwise inaccessible area. The real value of Gemenc is the untouched floodplain forest, the wildlife can be discovered within the framework of the narrow-gauge railway on foot or by bike, as the Szekszárd-Baja section of the Great Plain Blue Tour also leads through the floodplain forest.

A similarly unique line is the Mahóca wing line of the Lillafüred State Forest Railway in the eastern Bükk Mountains, which today can only run on a very short section, according to a special train schedule. The role of the Old Lake narrow-gauge railway in Hortobágy, which serves the local fish farm, is also important, it handles the traffic among the lakes, both during fishing and feeding. This method is not unique, as small fishponds operate in several places

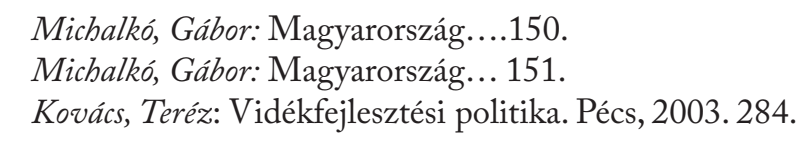


in Hungary (Tömörkény, Fehér-tó). ${ }^{5}$ Hortobágy stands out because the management of the Hortobágy National Park has created a new attraction without a new infrastructure investment, using the narrow-gauge railway, which until then was used only for industrial purposes. In the tourist offer of Hortobágy, it also created the opportunity to get an insight into the everyday life of the fishponds and the birdlife of the area.

However, the infrastructure of narrow-gauge railways includes not only tracks but also buildings. The buildinds can be an integral part of tourism as elements of static infrastructure. The static elements of tourism include those that are fixed and thus serve the exploration and sale of attractiveness. These are mostly buildings, ${ }^{6}$ but in the case of narrow-gauge railways we can also list the artefacts that form part of the lines. In many cases, the stations themselves, the station buildings are also attractive, thanks to the fact that most of them date back to the $20^{\text {th }}$ century. They were built in the first decades of the $19^{\text {th }}$ century and can still be seen in their original condition. For example, the Lillafüred station of the Lillafüred State Forest Railway station, or the Almamellék State Forest Railway, which is the legacy of the former KaposvárSzigetvár major railway. Both buildings have an exhibition of the narrow-gauge railways. A similar attraction is the pavilion of the Millennium National Exhibition, which is currently being rebuilt. It will be the wedge of the Pörböly Ecotourism Center. ${ }^{7}$ Of course not only former buildings can be part of an attractive static infrastructure. The forest school of Pörböly (Gemenc State Forest Railway) presenting the fauna of the floodplain forest and the Budakeszi Wildlife Park in the immediate vicinity of the Budapest Children's Railway, which also has a stop on the railway.

There are forest schools along several of our domestic narrow-gauge railways, which are important infrastructural elements of environmentally conscious education. Elements related to static infrastructure that appear specifically in traffic are various artefacts such as bridges and tunnels, which are also present on our narrow-gauge railways. The youngest bridges are located on the Kemence Forest Museum Railway. However, the most interesting and spectacular bridges are located on the Lillafüred State Forest Railway (LÁEV) line, and are not only notable from a tourist's point of view, but also from a pontooner point of view. The size of the Deep Valley Bridge stands out from the artefacts of Hungarian narrow-gauge railways, while the Arch Bridge on the southern side of Lake Hámori is unusual and unique in its shape. The two longest tunnels of our Hungarian narrow-gauge railways are also on the LÁEV line, both in Lillafüred, in front of the station and right after the station. This solution is a special experience, as arriving at and leaving the station gives tourists an experience they will not get anywhere else. The Hárshill tunnel of the Children's Railway in Budapest was built for a similar purpose in 1950, which enriches the railway journey with new experiences in addition to overcoming the ascent more efficiently.

\section{Dynamic infrastructure}

However, their most significant role is as part of the dynamic infrastructure: the railway vehicle. It transports passengers to the attraction, or it is part of the local transport, and due to its nature it attracts tourists. ${ }^{8}$ Most of the narrow-gauge railways fall into the category of dynamic infrastructure. This stems from the fact that the narrow-gauge railways in use to this day were built almost without exception to explore forests. One of the most beautiful lines exploring the forests is the

\footnotetext{
5 Pavletits, Péter: Ipari kisvasúttal a tavak között. Tömörkényi pillanatok. In: Indóház vasúti magazin 6 (2010) 6. 56-57.

6 Michalkó, Gábor: Magyarország...288.

7 Pavletits, Péter: Fejezetek a Gemenci Erdei Vasút történetéből. In: Indóház vasúti magazin 15 (2019) 6. 54-57.

8 Michalkó, Gábor: Magyarország...170.
} 
Picture 1: Train with steam engine MÁV Lillafüred State Forest Railway, which winds its way 490,039 at the Children's Railway (2015)

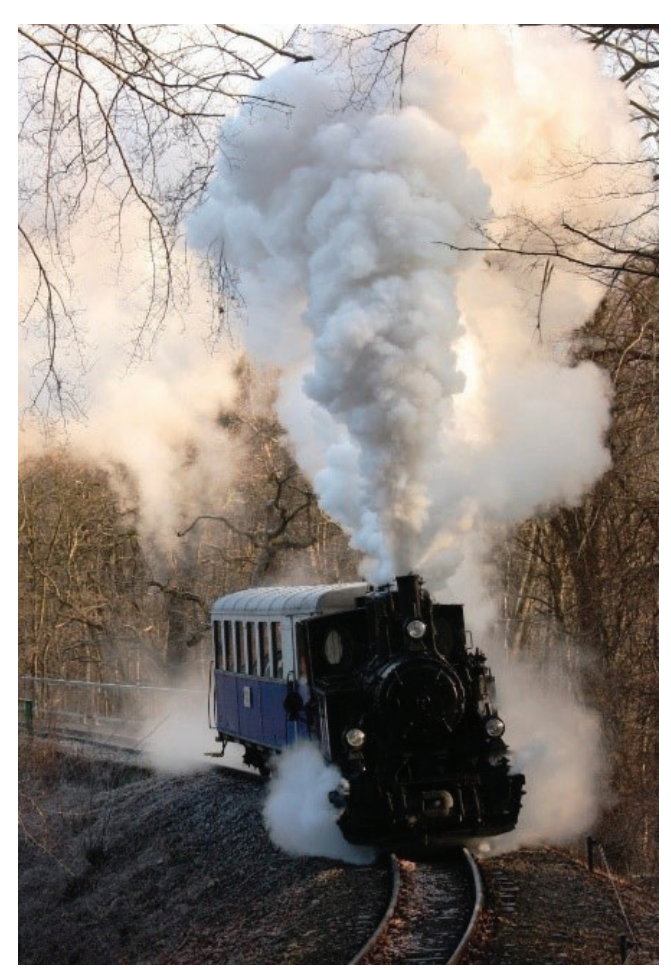

from Diósgyör to the end of both lines in the forests of the Bükk Mountains for a total length of more than 20 kilometers. The line of the other narrow-gauge railway in Bükk, the Szilvásvárad State Forest Railway, which runs through the deservedly famous Szalajka Valley, is equally exciting. The valley can be explored on foot, but even by car, the railway is just one of the alternatives here. Thanks to this, it is not so much the railway itself, but the Szalajka Valley and its beauty that is attractive to tourists, so the narrow-gauge railway fully meets the requirements of dynamic infrastructure in this approach.

We should not forget the narrrow-gauge railways in Somogy either, as both of the lines in Almamellék and Mesztegnyő were built to explore the forests, and their remaining lines still run in the forests today. ${ }^{9}$ Thus, they are also part of the dynamic infrastructure of tourism.

An important part of the dynamic infrastructure is also the special vehicle fleet of each railway plant. MÁV (Hungarian State Railways) has a forest knowledge laboratory car for kindergarten and primary school groups on the Széchenyi Hill Children's Railway and Photo by Péter Pavletits the Csömödér State Forest Railway. Bicycles and prams are also used on MÁV's two narrow-gauge lines, Balatonfenyves and the Budapest Children's Railway. An earlier example is also known, the Lillafüred State Forest Railway acquired a saloon car in 1929. The saloon car transported the illustrious guests to the Lillafüred Palace Hotel. Among other things, several members of the Bethlen government traveled regularly with this saloon car. ${ }^{10}$

\section{Appearance of attractiveness and seasonality}

Attraction is difficult to define and describe precisely because there are a lot of subjective elements. In the multitude of narrow-gauge railways, we can definitely highlight and call it a real attraction, the existence of which highlights a line due to its interestingness and thus arouses more interest from tourists and hikers than other similar railway lines. Here again, elements of static infrastructure can be mentioned that may attract tourists, or even areas explored by railways as natural values. In addition to these, it is much more important that almost all domestic narrow-gauge railways have some depth of attraction. There are

some that have only a local level, some have Photo by Péter Pavletits

Picture 2: Train at Kemence Forest Museum railway on 17th March 2020.

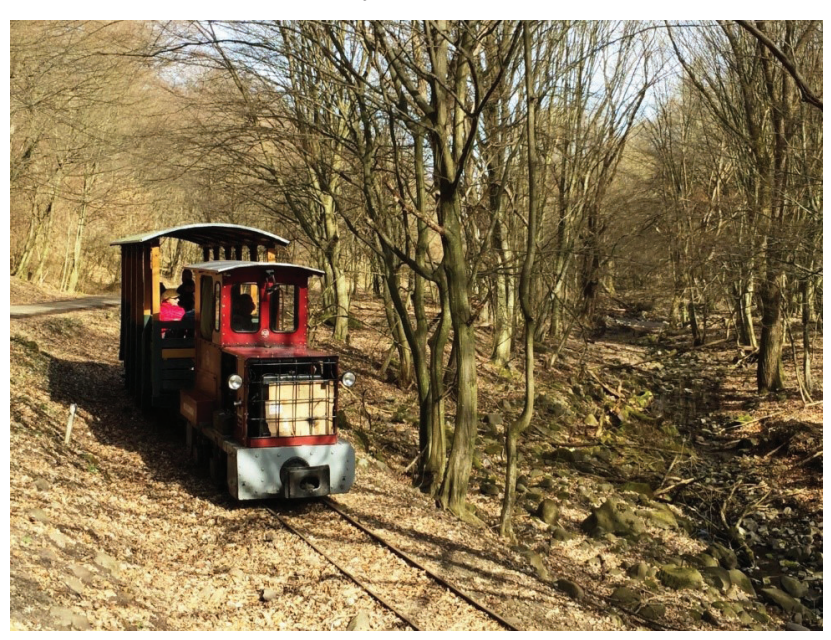

\footnotetext{
9 Pavletits, Péter - Tusnádi, Csaba Károly: A Zselici csühögő. In: Indóház vasúti magazin 14. (2018) 4. 50-54.

10 Fodor, Illés: A keskeny nyomközủ vasutak közlekedés földrajzi jelentősége Magyarországon. ELTE TTK. Budapest, 2003. 25.
} 
a regional appeal, but we also have some narrow-gauge railways that can be categorized as having a national appeal. ${ }^{11}$ Attraction is therefore a theoretical thing that every narrow-gauge railway in Hungary has. Even in countries such as Switzerland, where narrow-gauge railways are an integral part of the country's rail network, there are several lines that are also extremely popular with tourists. ${ }^{12}$ In Hungary, narrow-gauge railways are a great tourist attraction in their own right. However, their appeal is not the same. There are railways that offer the attraction on their own. Such railways are the museum railways, two of them in Hungary are the Széchenyi Museum Railway in Nagycenk, owned by the Hungarian Transport Museum and the Kemence Forest Museum Railway, operated by the Circle of Friends of Narrow-gauge Railways (KBK).

A special attraction is the steam locomotives and the nostalgia trains they tow, which will slowly be found on all our narrow-gauge railway lines. In addition to the masterpieces of the Hungarian mechanical engineering industry, in many cases the steam locomotives purchased and renovated from abroad, mainly from Transylvania, impose kilometers on the various networks of the country. Due to both its historical and technical peculiarities, one of the steam locomotives is LILLA, which is the only steam locomotive with carriage operating on the country's narrowgauge railways, owned by the Lillafüred State Forest Railway. The locomotive is currently on display at Majláth station due to a lack of funds for its renovation. It adds to its value that it is the only steam engine in Hungary that operates where it originally served. In this case LÁEV has a national significance.

In addition to steam locomotives, the hundred years old Ganz motor car is an interesting and important souvenir of the past of the Hungarian narrow-gauge railway history. It works nowadays in Budapest on the Children's Railway with its associated trailers. These vehicles started their service at the Szinva Valley Forest Railway (SzEV), the legal predecessor of the Lillafüred State Forest Railway in 1929. ${ }^{13}$ These vehicles are one of the biggest attractions of the Budapest Children's Railway alongside the nostalgia trains hauled by steam locomotives.

Diesel locomotives may also be of interest on the lines of the already mentioned Kemence Forest Museum Railway, as we do not find Mk48 or Mk45 locomotives commonly used in Hungary here, but used motor locomotives purchased from closed mines and various commercial railways. There are only one or two more working specimens in the country. Another curiosity among motor locomotives is the B26 series diesel locomotive operating at Lillafüred State Forest Railway, which was saved by the railway management during the liquidation of the world famous Szerencs sugar factory. ${ }^{14}$ This is the last surviving and still operating locomotive of this type in Hungary. Thus, if we examine the Hungarian narrow-gauge railways from the point of view of technical curiosities, we can state that the Nagycenk Széchenyi Museum Railway, the Kemence Forest Museum Railway, the Széchenyi Hill Children's Railway and the Lillafüred State Forest Railway have a greater attraction than the others.

In addition to attraction, it is important to talk about seasonality. The latter is an important element of tourism. Not all attractions offer the same experience in summer as in winter, they are not the same attraction in all seasons. This is especially true for outdoor attractions such as our narrow-gauge railways. Not only the narrow-gauge railways themselves are seasonal, but in many cases so are the sights they explore or accede. Whether it is the Szalajka Valley or Gemenc, they offer a much greater experience in summer than in winter. Thus, it can be said that seasonality appears almost without exception in narrow-gauge railways. On most lines, this

11 Michalkó, Gábor: Magyarország...200.

12 Pavletits, Péter: A Parsenn iker siklóvasút, a Parsennbahn. In: Indóház vasúti magazin 15 (2019) 2.52-54

13 Szécsey, István: Hetvenéves a Lillafüredi Állami Erdei Vasút (LÁEV) és a MÁV Rt. Széchenyi-hegyi Gyermekvasút Ganz-és Orenstein \& Koppel-gyártmányú motorszerelvénye. Budapest, 1999. 40.

14 Pavletits, Péter: Kötöttpályán Kocsonthátra és a Rosszmalom-tanyához. Fejezetek a Szerencs környéki gazdasági vasutak történetéből. In: Indóház vasúti magazin 16 (2020) 6. 50-54. 
is so embodied that traffic is completely disrupted during the winter. During the winter, there are only a few lines with scheduled plants, but most lines run special trains, which are mainly requested by railway lovers. There are very few railways in Hungary that also operate in the 2020-2021 winter schedule period. Such are the Balatonfenyves Economic Railway, which also performs the only public task, and the Széchenyi Hill Children's Railway, which is also managed by MÁV. The Children's railway welcomes tourists all year round - with a Monday break during the winter scheduling period. Based on its location, it is accessible all year round and the train experience is unforgettable at all times of the year. Altough there are no seasonal attractions along the line, the trip itself is a great experience. People living in Budapest and in the capital's agglomeration can easily use the trains running between Hüvösvölgy and Széchenyi Hill even on a weekday afternoon. A special advantage of the railway is that it runs a scheduled nostalgia train all year round, with both steam traction and Ganz motor car operation.

The privately owned narrow-gauge railway in Mecsek, which runs between the Pécs amusement park and the zoo, also runs seasonally on weekdays; on Sundays and public holidays we can board the trains in all seasons.

All of the forest railways run seasonally. The heaviest traffic in the winter is handled by the narrow-gauge railway running between Kismaros and Királyrét, which runs in the late autumn and winter months (November-February) on five days with leisure and non-working days, now under reconstruction. This is also due to the relatively high number of 110,000 passengers. Due to the proximity of Budapest and the good accessibility of Kismaros, the line is in a lucky position. Good basic infrastructure allows millions of metropolitan and agglomeration residents to visit the narrow-gauge railway even on winter weekends. The Gemenc State Forest Railway also runs seasonally, but here the seasonality does not mean winter and summer. The railway also operates in winter, the traffic is continuous every day, if only with a few trains. The operation of the railway is affected by the flooding of the Danube. During floods, part of the track is usually submerged, so there is a temporary downtime on the line during spring and autumn floods.

However, most narrow-gauge railways do not have any passenger transport during the winter months. Only a few special trains wear the track at this time. This has long been a common practice on several railways, but financial difficulties, declining funding, the crisis and the growing shortage of tourists in the winter also led to the shutdown of the Lillafüred State Forest Railway in the winter of 2009/2010. In the case of the traffic of short-distance railways, the most important factor is the attraction, which directs the attention of hikers and tourists towards the railway. The more attractions there are near the lines, and the greater the attraction of the railway itself, the heavier the passenger traffic. Seasonality is also extremely prominent in traffic data. In several cases, the number of attractions decreases in winter, thus reducing the attractiveness of the railways, so that they carry far fewer passengers during the winter than in summer.

\section{The tourist milieu}

By tourist milieu we mean the attractiveness of the destination, the totality of the experiences gained there. ${ }^{15}$ If we want to put narrow-gauge railways in this context, we look at the impressions a tourist makes when traveling on a narrow-gauge railway. In order for a visitor to visit a particular destination over and over again, we need to provide more than average, enriching us with impressions and experiences that we cannot get elsewhere. The tourist milieu can also manifest itself in a psychological sense, the color, shape and smell complex of the landscape undoubtedly has a spiritual impact on the traveler. Nostalgia journeys on narrow-gauge railway steam locomotives certainly operate with these spiritual influences.

15 Michalkó, Gábor: A turisztikai milioo földrajzi értelmezése. In: Tér és Társadalom 19 (2005) 1. 43-63. 
The narrow-gauge railway Picture 3. Train at Felsőtárkány Forest Railway (2015) ride itself offers an unforgettable experience, thus meeting the expectations of the tourist milieu. It is also important to stimulate the geographical conditions of the destination. The upper terminus of the Felsőtárkány Forest Railway offers an excellent hiking opportunity to Hungary's only geyser, the Red Stone Spring, which is undoubtedly a unique geographical phenomenon during the spring thaw. There are several railway lines that stand out from the other lines either with their technical curiosity - the vehicle collection of the Kemence Museum

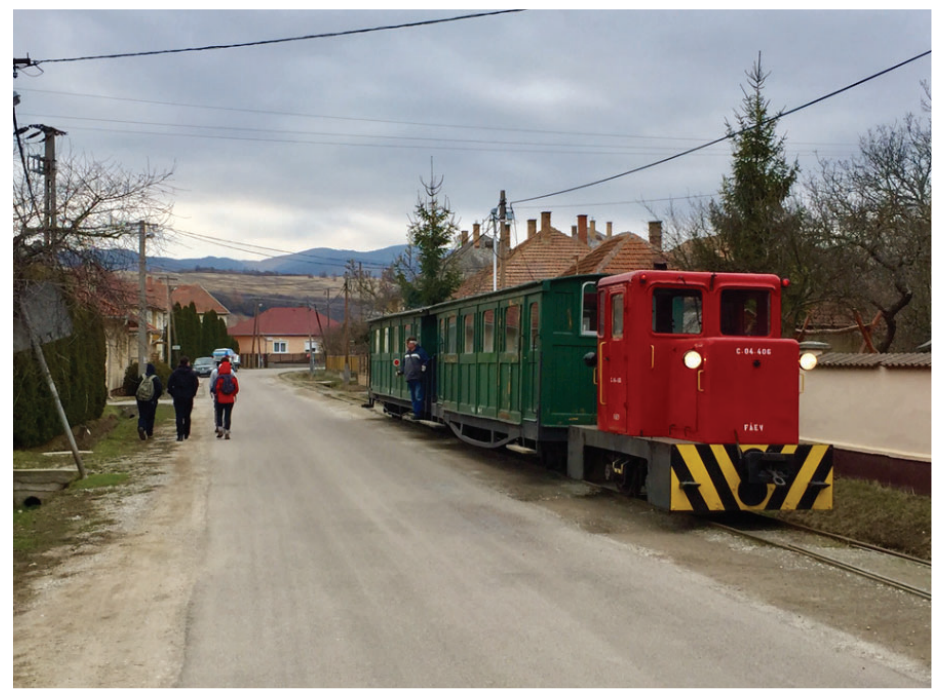

Photo by Péter Pavletits

Railway - or with the line drawing - the peak inverter of the Nagybörzsöny Forest Railway. The recently re-installed water crane of the Széchenyi Hill Children's Railway also enhances the travel experience by being the only one in the country to install steam locomotives using the original method.

But in the same way, a tourist who travels from a mountainous area to, for example, the Hortobágy narrow-gauge railway, which winds among fishponds, ${ }^{16}$ or from the lowlands to the Slovenian Postojna Cave Railway or the Csorba Lake with the cog railway, may have a higher milieu than others. ${ }^{17}$

The tourist milieu is perhaps even more complex and objective than other attractions in terms of narrow-gauge railways. This is due to the fact that they operate in different regions of the country, in different geographical environments. Thus, the milieu of the Pálháza Forest Railway is different, the Trans-Börzsöny forest is different, and the Csömödér State Forest Railway is different. These are not comparable with each other, however, in the passenger numbers it is somewhat traceable where the depth of the charm of the tourist milieu is present.

The condition of the local infrastructure and the means of transport that help to explore the attractions are also an important milestone. The importance of this was recognized by the two-stage financial support $(2017,2020)^{18}$ of the Hungarian Government, which helps the development of domestic narrow-gauge railways with billions of Forints.

16 Fodor, Illés: A halgazdasági kisvasutak. In: Indóház vasúti magazin 2 (2006) 5. 70-75.

17 Pavletits, Péter: Fogasléccel a Magas-Tátrába. In: Indóház vasúti magazin 11 (2015) 1.52-54.

18 Decision of Hungarian Government 1467/2017 for narrow-gauge railways with touristical purpose 